\title{
A Novel 2.3 Mb Microduplication of 9q34.3 Inserted into 19q13.4 in a Patient with Learning Disabilities
}

\author{
Shalinder Singh, ${ }^{1}$ Fern Ashton, ${ }^{1}$ Renate Marquis-Nicholson, ${ }^{1}$ Jennifer M. Love, ${ }^{1}$ \\ Chuan-Ching Lan, ${ }^{1}$ Salim Aftimos, ${ }^{2}$ Alice M. George, ${ }^{1}$ and Donald R. Love ${ }^{1,3}$ \\ ${ }^{1}$ Diagnostic Genetics, LabPlus, Auckland City Hospital, P.O. Box 110031, Auckland 1148, New Zealand \\ ${ }^{2}$ Genetic Health Service New Zealand-Northern Hub, Auckland City Hospital, Private Bag 92024, Auckland 1142, New Zealand \\ ${ }^{3}$ School of Biological Sciences, University of Auckland, Private Bag 92019, Auckland 1142, New Zealand
}

Correspondence should be addressed to Donald R. Love, donaldl@adhb.govt.nz

Received 1 July 2012; Accepted 27 September 2012

Academic Editors: L. Cvitanovic-Sojat, G. Singer, and V. C. Wong

Copyright (c) 2012 Shalinder Singh et al. This is an open access article distributed under the Creative Commons Attribution License, which permits unrestricted use, distribution, and reproduction in any medium, provided the original work is properly cited.

\begin{abstract}
Insertional translocations in which a duplicated region of one chromosome is inserted into another chromosome are very rare. We report a 16.5-year-old girl with a terminal duplication at 9q34.3 of paternal origin inserted into 19q13.4. Chromosomal analysis revealed the karyotype 46,XX, $\operatorname{der}(19)$ ins $(19 ; 9)(\mathrm{q} 13.4 ; \mathrm{q} 34.3 \mathrm{q} 34.3)$ pat. Cytogenetic microarray analysis (CMA) identified a $\sim 2.3 \mathrm{Mb}$ duplication of $9 \mathrm{q} 34.3 \rightarrow$ qter, which was confirmed by Fluorescence in situ hybridisation (FISH). The duplication at $9 \mathrm{q} 34.3$ is the smallest among the cases reported so far. The proband exhibits similar clinical features to those previously reported cases with larger duplication events.
\end{abstract}

\section{Clinical Report}

The proband was born prematurely at 35 weeks gestation with a birth weight of $2040 \mathrm{~g}$. She required nasogastric tube feeding during the first week of life. During infancy, she was investigated for hypotonia and associated plagiocephaly; a brain MRI scan showed no abnormalities. She also had difficulties swallowing solids until the age of 2 years with ongoing tendency to drooling and keeping her mouth open. She walked at 2 years and 3 months of age. Her speech began developing at around that time. At school, she demonstrated age appropriate reading and writing skills, but required additional help in maths. However, the degree of her learning difficulty was minimal and psychometric assessment was not deemed to be necessary. She was also noted to have difficulties in gross motor and particularly fine motor skills and required assistance from an occupational therapist. An ophthalmic assessment at 16 years of age demonstrated myopia, with visual acuity of 6/24 in the right eye and 6/12 in the left eye. Fundoscopy revealed the presence of pigmentary changes in both posterior poles.
She was reviewed at the genetics clinic at 16.5 years of age. At that time, she was continuing to make good academic progress although she was receiving some input from the learning support unit attached to her school. Her height was at the 50th centile, weight at the 25th centile, and head circumference between the 25th and 50th centiles. Facial dolichocephaly and asymmetry were noted. The eyes were mildly deep set. She had a short philtrum and mild microganthia (Figures 1(a) and 1(b)), with a high arched palate. There was distal tapering of the fingers with radial clinodactyly of the middle three fingers (Figure 1(c)). She had long halluces, curly toes, and bilateral hallux valgus (Figure 1(d)). A mild scoliosis was also noted.

\section{Chromosome Analysis}

Conventional G-banded chromosome analysis was performed on peripheral blood samples taken from the proband and her parents. 


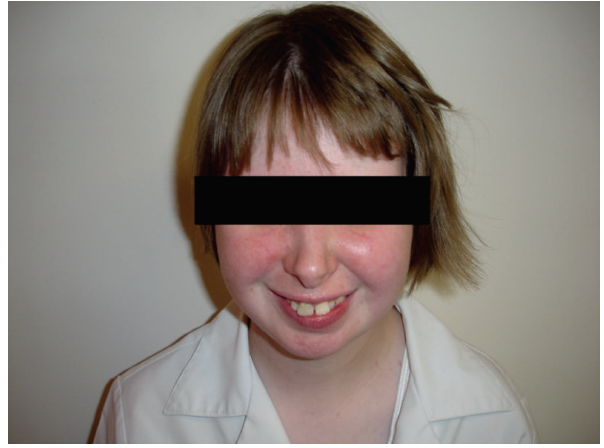

(a)

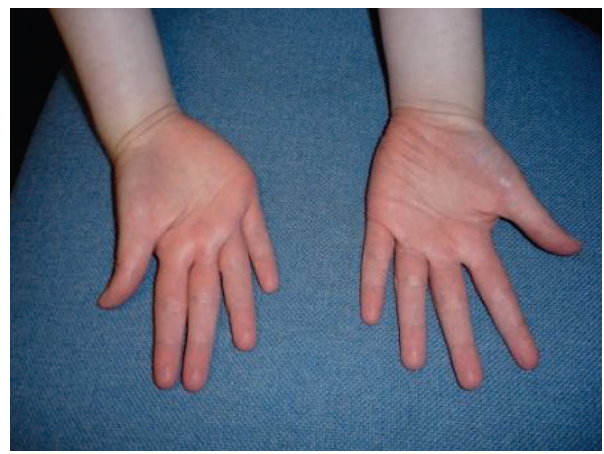

(c)

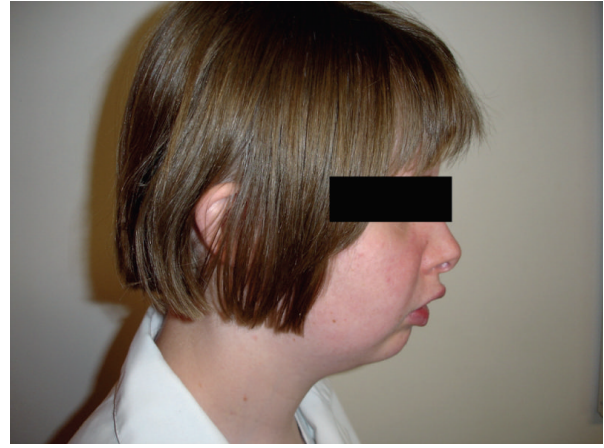

(b)

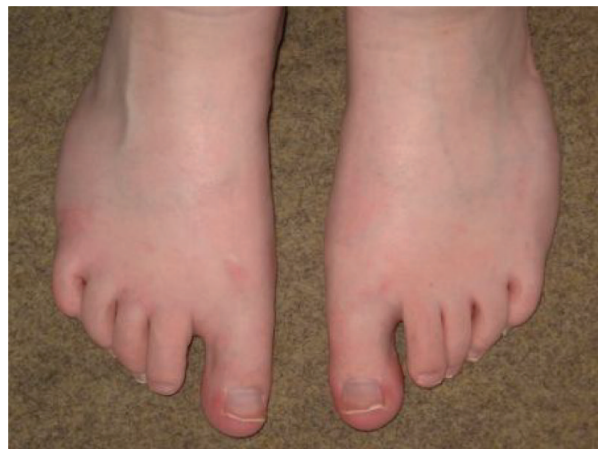

(d)

FIGURE 1: Clinical features of the patient at the age of 16.5 years. Frontal view (a) shows the short philtrum. Lateral view (b) shows mild micrognathia. (c) shows distal tapering of the fingers with radial clinodactyly of the middle three fingers, and (d) shows Long halluces, curly toes, and bilateral hallux valgus.

Genome-wide copy number analysis was determined from genomic DNA samples using the Affymetrix Cytogenetics Whole-Genome $2.7 \mathrm{M}$ array, according to the manufacturer's instructions. Regions of copy number change were calculated using the Affymetrix Chromosome Analysis Suite software (ChAS) v.1.0.1 and interpreted with the aid of the UCSC genome browser (http://genome.ucsc.edu/; Human Mar. 2006 (hg18) assembly).

Chromosomal analysis showed a female karyotype 46,XX,der(19)ins(19;9)(q13.4;q34.3q34.3) for the proband (Figure 2(a)). The father's karyotype was 46,XY,ins $(19 ; 9)$ (q13.4;q34.3q34.3) (Figure 2(d)) and the mother's karyotype was normal (data not shown). The array revealed a terminal duplication of approximately $2.3 \mathrm{Mb}$ at $9 \mathrm{q} 34.3$, and the proband's molecular karyotype was arr 9q34.3(137,864,059140,171,337)x3 (Figure 3; UCSC Genome Browser-NCBI Build 36, Mar. 2006 assembly).

FISH confirmed that a segment of region $9 \mathrm{q} 34.3$ was inserted into the region 19q13.4 using the locus-specific probe D9S325, with two signals on the chromosome 9 homologues present in the proband (Figures 2(b) and $2(\mathrm{c}))$. FISH using the probe specific for the $19 \mathrm{q}$ terminal region confirmed that the subtelomeres of the derivative chromosome 19 were intact. FISH findings from the father demonstrated an apparently balanced translocation: part of region $9 q 34.3$ was inserted into $19 q 13.4$, thus confirming the parental origin of the derivative chromosome 19 (Figures 2(e) and 2(f)). The duplicated region encompasses approximately 92 genes, which are likely to contribute to the proband's phenotypic features.

\section{Discussion}

Patients with $9 \mathrm{q}$ duplications have overlapping features, which include variable degrees of developmental delays, learning or intellectual deficits, facies characterised by dolicocephaly, asymmetry, deep set eyes or small palpebral fissures, high arched palate, micrognathia and digital anomalies including arachnodactyly, camptodactyly and clinodactyly. Furthermore, the finding of long halluces appears to be a common and distinctive feature in patients with a pure duplication, although many other reported cases carry copy number changes other than $9 \mathrm{q}$ duplications [1-8].

In this study, we report a small $\sim 2.3 \mathrm{Mb}$ duplication of $9 q 34.3$ detected by CMA. Our patient displayed dolicocephaly and facial asymmetry, mildly deep-set eyes, short philtrum, mild microganthia, high arched palate, clinodactyly, mild scoliosis, mild myopia, and digital anomalies. A comparison of phenotypic anomalies of our patient with previously reported cases is summarised in Table 1.

Recently, Gijsbers et al. [8] reported a 16-year-old girl with a triplication and duplications in the $9 q 34.3$ region. 


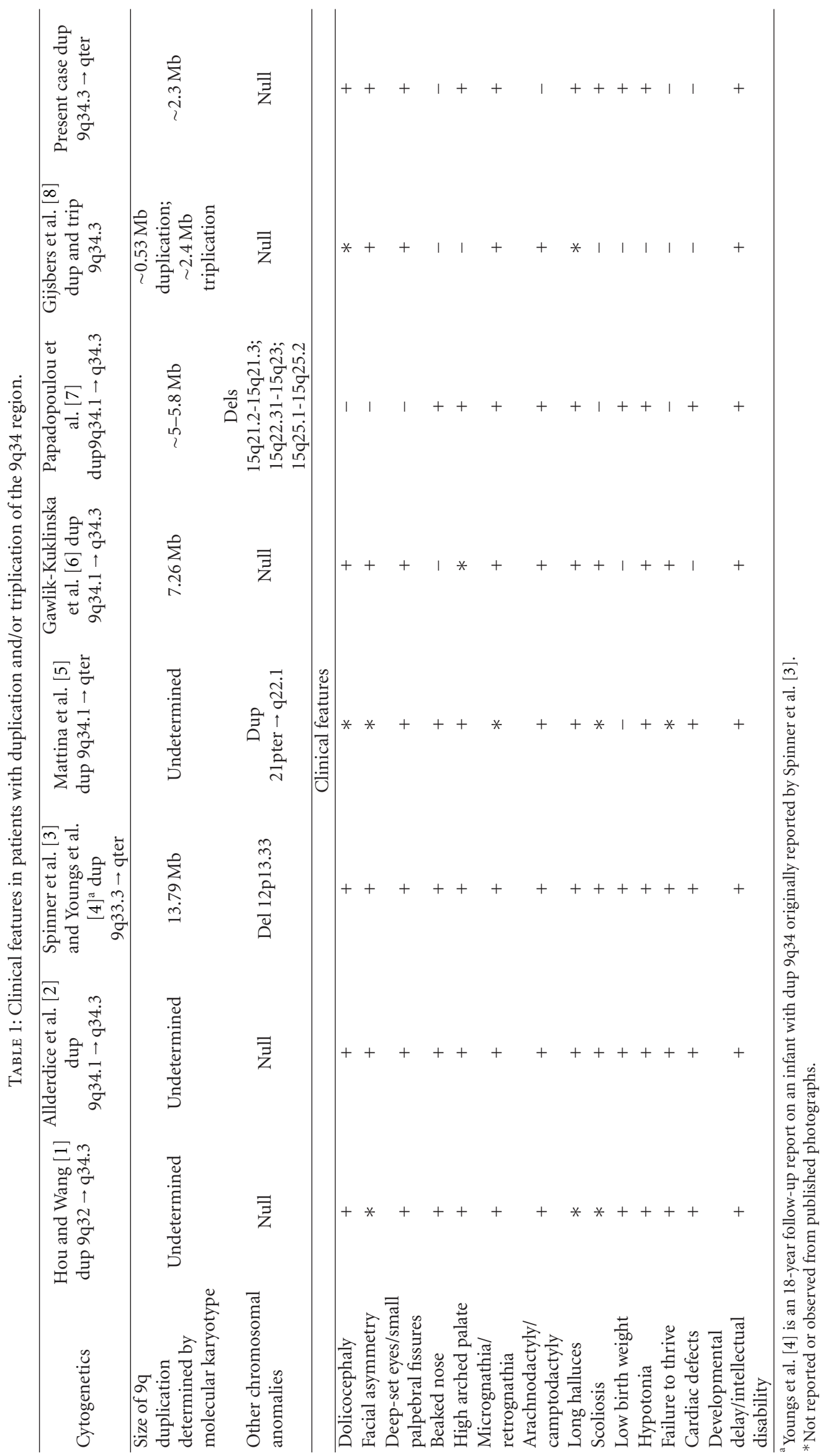




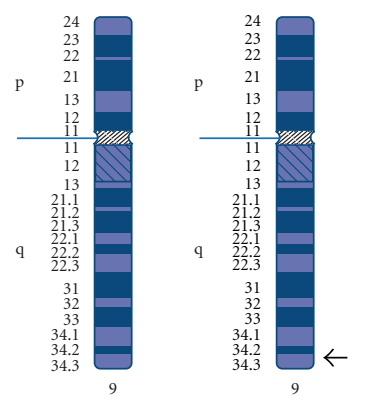

(a)

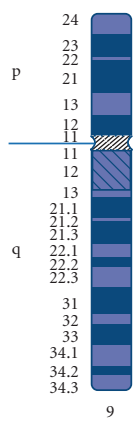

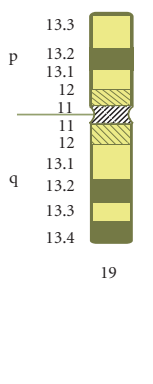

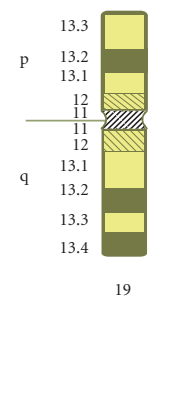

(d)
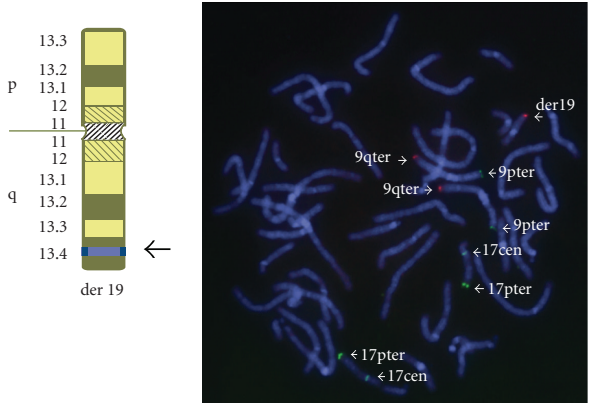

(b)

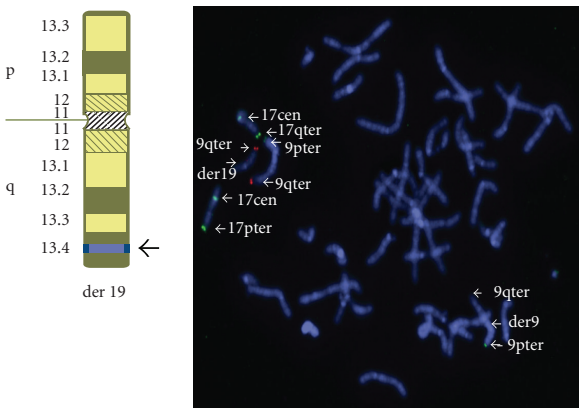

(e)

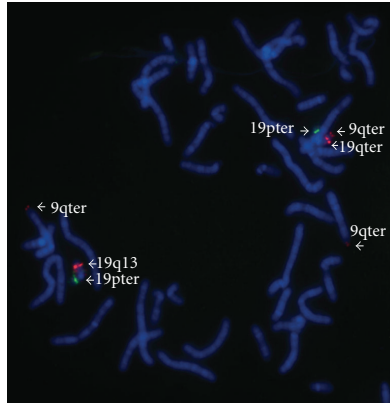

(c)

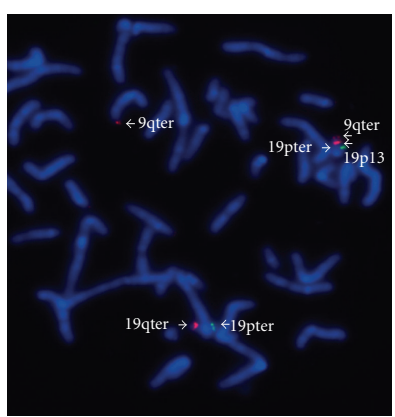

(f)

FIGURE 2: Cytogenetics and FISH analysis of proband and father. ((a)-(c)) and (d-f) show the analysis of the proband and father, respectively. Ideograms of chromosomes 9 and 19 show that part of region $9 q 34.3$ is inserted into region 19q13.4 in the proband (a), and the father is a carrier of a balanced insertional translocation (panel d). FISH analysis used probes for 9pter (305J7-T7), 9qter (D9S325), 19pter (129F16/SP6), 19qter (D19S238E), 19q13 (GLTSCR1/GLTSCR2/CRX), while 17cen and 17q used control probes ((b)-(c) for the proband, and panels (e)-(f) for the father). These panels confirm that the part of region $9 \mathrm{q} 34.3$ is inserted into region 19q13.4. The subtelomeres of chromosome 19 were intact (the probes for 19pter (129F16/SP6) and 19qter (D19S238E) were used; image not shown).

The authors noted that the clinical features of their proband overlapped with those in one previous report [2], which was a "pure" 9q34.3 duplication case. The same dysmorphic features are shared with the proband reported here, but feeding difficulties, scoliosis, and severe mental retardation are absent. The more severe phenotype reported by Gijsbers et al. [8] may be attributed to a larger $\sim 2.9 \mathrm{Mb}$ region of duplicated and triplicated subregions (chr9q34:137,265,834$140,207,437)$ that encompasses approximately 100 genes. In our case, approximately 92 genes are duplicated in a $\sim 2.3 \mathrm{Mb}$ region (chr9q34.3: 137,864,059-140,171,337).

Of the genes contained within the duplicated region detected in our patient, eleven are present in the Online Mendelian Inheritance in Man (OMIM; http://www.ncbi .nlm.nih.gov/omim) morbid map, and of these, all but NOTCH1 are associated with autosomal recessive disease and homozygosity for terminating mutations (Table 2). As a consequence, these OMIM genes do not appear to play a role in the clinical phenotype reported here which is likely to be caused by gene overexpression, due to the increased copy number of the $2.3 \mathrm{Mb}$ region of chromosome 9 , rather than haploinsufficiency.

In the mouse, upregulation of $\mathrm{NOTCH}$ activity appears to be associated with an increase in the number of interneuronal contacts and the cessation of neurite growth [9]. In addition, the NOTCH signalling pathway plays a pivotal role in embryo development. It is likely, given the mathematical modelling undertaken by Raya et al. [10], that increased expression of NOTCH1 would have an impact on the level of NOTCH1-associated subcomplexes, and hence alter developmental and physiological outcomes. That NOTCH1 overexpression may be the principal underlying gene responsible for the phenotype of our patient remains speculative at this stage. It is also possible that the site of insertion on chromosome 19 may affect the expression of chromosome 19 genes, which may play a role in the phenotype reported here. Unfortunately, the array data does not provide any clues regarding the specific site of insertion on chromosome 19.

In summary, the proband reported here is a new addition to the rare collection of dup $9 \mathrm{q} 34$ cases. Our patient has developed a mild form of the clinical features described in other $9 \mathrm{q} 34$ cases, possibly due to the smaller affected region. Patients with shorter dup $9 \mathrm{q} 34$ tend to have a better prognosis and would benefit from special education with input from their parents [2]. It is hoped that with increased reporting of similar cases, dosage changes and breakpoints in this region can be more clearly correlated to phenotypic features to aid genetic counselling and medical management. 


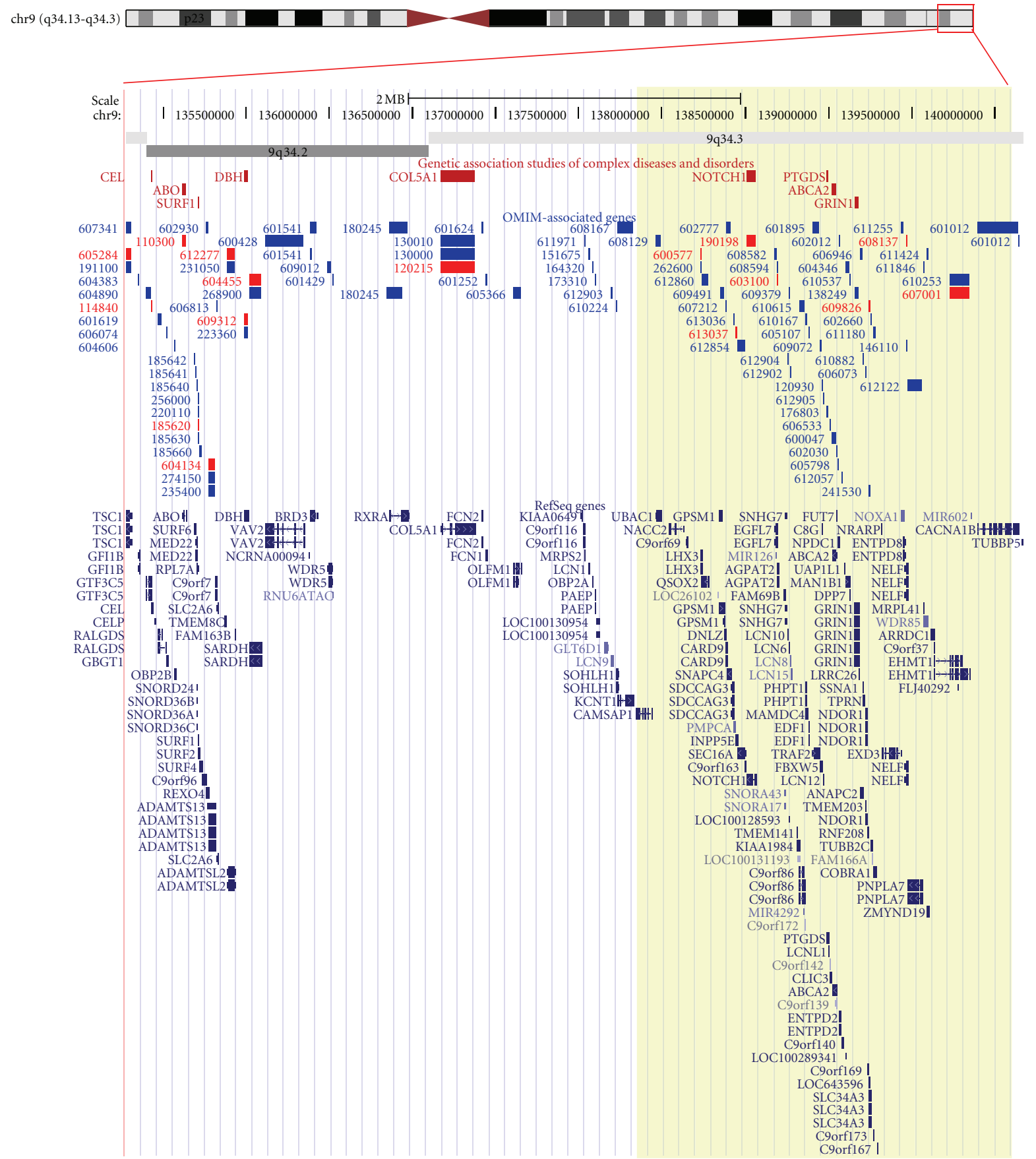

Papadopoulou et al. [7]

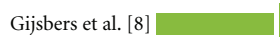

Present case

FIGURE 3: Location and extent of 9q34 duplications. UCSC Genome Browser (March 2006 (hg18) assembly) view of the chromosomal region 9q34.13-q34.3 (chr9:134,776,210-140,171,337) is shown, together with Refseq, OMIM, and GAD genes. The bottom panel shows the location and extent of the 9q34.3-qter region of the patient described here, and of other cases reported in the literature. Note: the region highlighted in yellow is the $\sim 2.3 \mathrm{Mb}$ region duplicated in our case, and the thicker green block represents the triplicated region reported by Gijsbers et al. [8]. 
TABLE 2: Duplicated region and OMIM genes.

\begin{tabular}{|c|c|c|c|c|}
\hline OMIM & Protein & Gene & Disorder & Molecular genetics \\
\hline 600577 & LIM/homeodomain protein LHX3 & LHX3 & $\begin{array}{l}\text { Combined pituitary } \\
\text { hormone deficiency-3 }\end{array}$ & $\begin{array}{l}\text { Homozygosity for intragenic } \\
\text { deletion/nonsense mutation }\end{array}$ \\
\hline \multirow[t]{2}{*}{613037} & Inositol polyphosphate-5-phosphatase & INPP5E & Joubert syndrome 1 & $\begin{array}{l}\text { Homozygosity for mutations in the } \\
\text { INPP5E gene that lead to decreased } \\
\text { phosphatase activity }\end{array}$ \\
\hline & & & $\begin{array}{l}\text { Mental retardation, truncal } \\
\text { obesity, retinal dystrophy, } \\
\text { and micropenis }\end{array}$ & $\begin{array}{l}\text { Homozygous nonsense mutation detected } \\
\text { in the INPP5E gene }\end{array}$ \\
\hline 607212 & $\begin{array}{l}\text { Caspase recruitment domain-containing } \\
\text { protein } 9\end{array}$ & CARD9 & $\begin{array}{l}\text { Autosomal recessive form } \\
\text { of familial chronic } \\
\text { mucocutaneous candidiasis }\end{array}$ & $\begin{array}{l}\text { Homozygous nonsense mutation in the } \\
\text { CARD9 gene }\end{array}$ \\
\hline \multirow[t]{2}{*}{190198} & $\begin{array}{l}\text { Notch, Drosophila, homolog of, } 1 \text {, } \\
\text { translocation associated Notch homolog; } \\
\text { NOTCH1 }\end{array}$ & NOTCH1 & Aortic valve disease & $\begin{array}{l}\text { Heterozygosity for nonsense/frameshift } \\
\text { mutations }\end{array}$ \\
\hline & & & $\begin{array}{l}\text { Leukemia, T-cell acute } \\
\text { lymphoblastic }\end{array}$ & \\
\hline 603100 & $\begin{array}{l}\text { 1-Acylglycerol-3-phosphate } \\
\text { O-acyltransferase } 2\end{array}$ & AGPAT2 & $\begin{array}{l}\text { Lipodystrophy, congenital } \\
\text { generalised, type 1; CGL1 }\end{array}$ & $\begin{array}{l}\text { Homozygous or compound heterozygous } \\
\text { mutations }\end{array}$ \\
\hline 613354 & Taperin & TPRN & $\begin{array}{l}\text { Autosomal recessive } \\
\text { nonsyndromic deafness-79 }\end{array}$ & Homozygous truncating mutations \\
\hline 604346 & Mannosidase, alpha, class 1B member 1 & MAN1B1 & $\begin{array}{l}\text { Mental retardation, } \\
\text { autosomal recessive } 15\end{array}$ & Homozygous mutations \\
\hline 138249 & $\begin{array}{l}\text { Glutamate receptor, ionotropic, } \\
\text { N-methyl D-aspartate } 1\end{array}$ & GRIN1 & $\begin{array}{l}\text { Mental retardation, } \\
\text { autosomal dominant } 8\end{array}$ & $\begin{array}{l}\text { Missense mutation; in-frame duplication } \\
\text { of codon } 560\end{array}$ \\
\hline 609826 & $\begin{array}{l}\text { Solute carrier family } 34 \\
\text { (sodium/phosphate cotransporter), } \\
\text { member } 3\end{array}$ & SLC34A3 & $\begin{array}{l}\text { Hypophosphatemic rickets } \\
\text { with hypercalciuria }\end{array}$ & Homozygous single-nucleotide deletion \\
\hline 608137 & $\begin{array}{l}\text { Nasal embryonic luteinizing } \\
\text { hormone-releasing hormone factor }\end{array}$ & NELF & $\begin{array}{l}\text { Hypogonadotropic } \\
\text { hypogonadism }\end{array}$ & A thr480-to-ala mutation in the NELF gene \\
\hline 607001 & Euchromatic histone methyltransferase 1 & EHMT1 & Kleefstra syndrome & $\begin{array}{l}\text { Heterozygous nonsense/frameshift } \\
\text { mutation, in the EHMT1 gene; terminal } \\
\text { deletions, interstitial deletions, derivative } \\
\text { chromosomes, and complex } \\
\text { rearrangements }\end{array}$ \\
\hline
\end{tabular}

The entries in this table were taken from the OMIM database (http://www.ncbi.nlm.nih.gov/omim).

\section{Acknowledgment}

The details of this case have been deposited in Decipher (https://decipher.sanger.ac.uk); ID 254186. The authors wish to state that there is no conflict of interests with any organization regarding the material presented in this paper.

\section{References}

[1] J. W. Hou and T. R. Wang, "Molecular cytogenetic studies of duplication $9 \mathrm{q} 32 \rightarrow \mathrm{q} 34.3$ inserted into 9q13," Clinical Genetics, vol. 48, no. 3, pp. 148-150, 1995.

[2] P. W. Allderdice, B. Eales, H. Onyett et al., "Duplication 9q34 syndrome," American Journal of Human Genetics, vol. 35, no. 5, pp. 1005-1019, 1983.

[3] N. B. Spinner, J. N. Lucas, M. Poggensee, M. Jacquette, and A. Schneider, "Duplication 9q34 $\rightarrow$ qter identified by chromosome painting," American Journal of Medical Genetics, vol. 45, no. 5, pp. 609-613, 1993.
[4] E. L. Youngs, T. McCord, J. A. Hellings, N. B. Spinner, A. Schneider, and M. G. Butler, "An 18-year follow-up report on an infant with a duplication of 9q34," American Journal of Medical Genetics A, vol. 152, no. 1, pp. 230-233, 2010.

[5] T. Mattina, M. Pierluigi, D. Mazzone, S. Scardilli, C. Perfumo, and F. Mollica, "Double partial trisomy 9q34.1 $\rightarrow$ qter and 21pter $\rightarrow$ q22.11: FISH and clinical findings," Journal of Medical Genetics, vol. 34, no. 11, pp. 945-948, 1997.

[6] K. Gawlik-Kuklinska, M. Iliszko, A. Wozniak et al., "A girl with duplication 9q34 syndrome," American Journal of Medical Genetics, Part A, vol. 143, no. 17, pp. 2019-2023, 2007.

[7] E. Papadopoulou, C. Sismani, C. Christodoulou, M. Ioannides, M. Kalmanti, and P. Patsalis, "Phenotype-genotype correlation of a patient with a "balanced" translocation 9;15 and cryptic 9q34 duplication and 15q21q25 deletion," American Journal of Medical Genetics A, vol. 152, no. 6, pp. 1515-1522, 2010.

[8] A. C. J. Gijsbers, E. K. Bijlsma, M. M. Weiss et al., "A 400 kb duplication, $2.4 \mathrm{Mb}$ triplication and $130 \mathrm{~kb}$ duplication of 9q34.3 in a patient with severe mental retardation," European Journal of Medical Genetics, vol. 51, no. 5, pp. 479-487, 2008. 
[9] N. Šestan, S. Artavanis-Tsakonas, and P. Rakic, "Contactdependent inhibition of cortical neurite growth mediated by Notch signaling," Science, vol. 286, no. 5440, pp. 741-746, 1999.

[10] Á. Raya, Y. Kawakami, C. Rodríguez-Esteban et al., "Notch activity acts as a sensor for extracellular calcium during vertebrate left-right determination," Nature, vol. 427, no. 6970, pp. 121-128, 2004. 


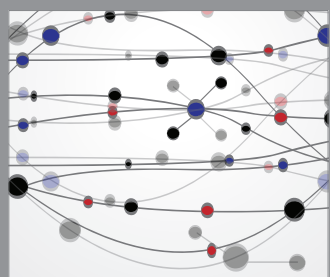

The Scientific World Journal
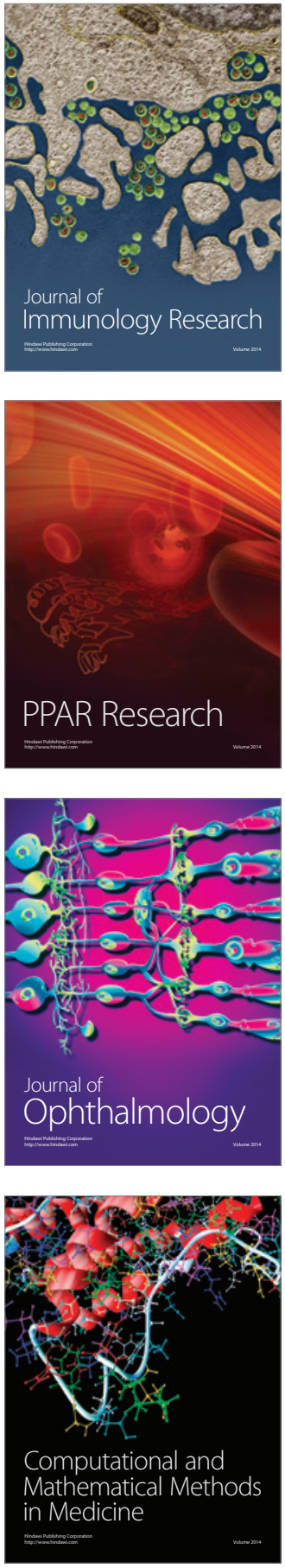

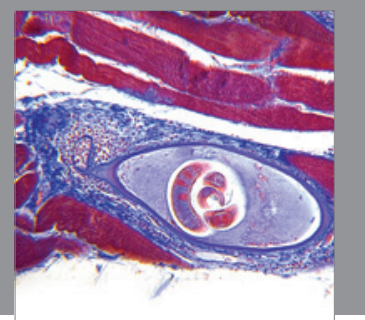

Gastroenterology

Research and Practice
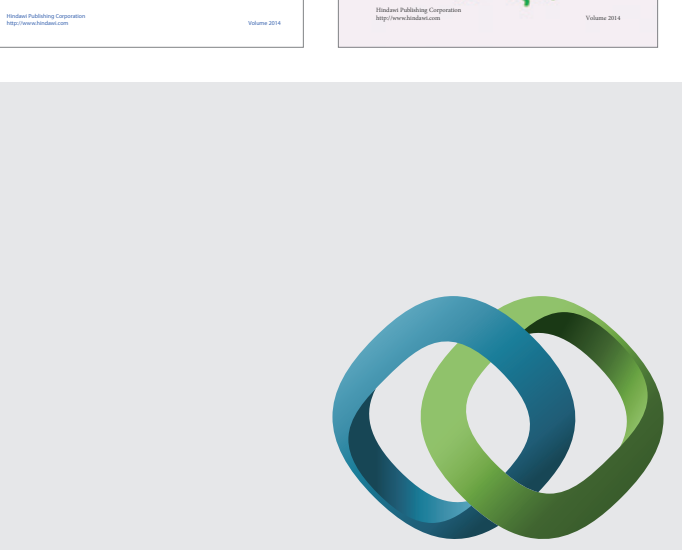

\section{Hindawi}

Submit your manuscripts at

http://www.hindawi.com
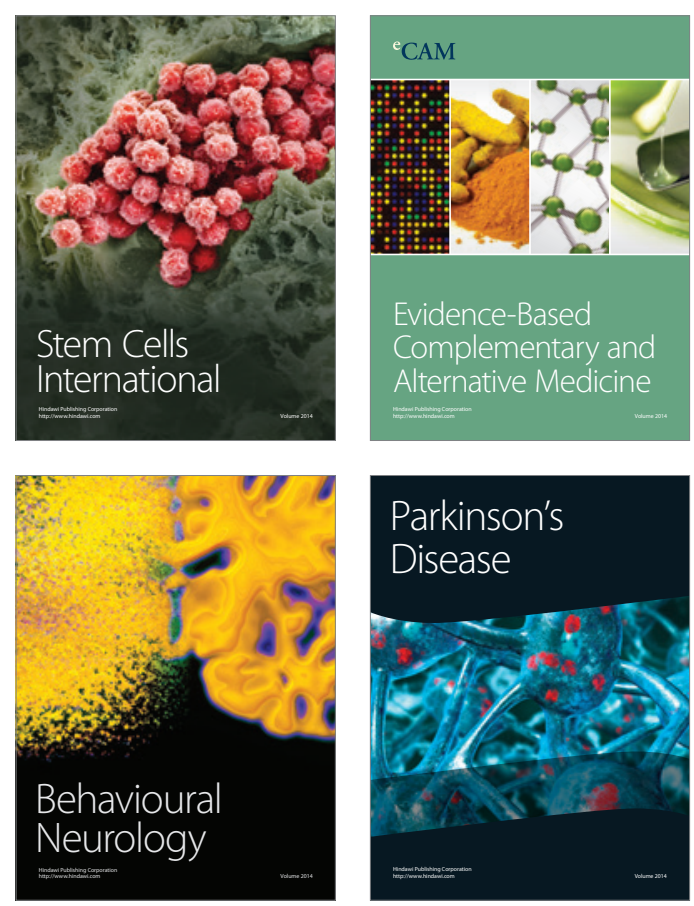

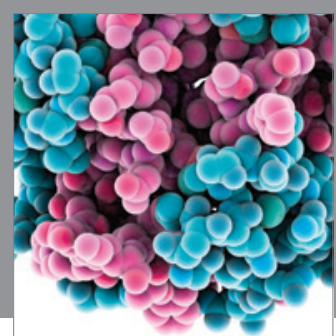

Journal of
Diabetes Research

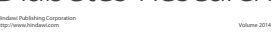

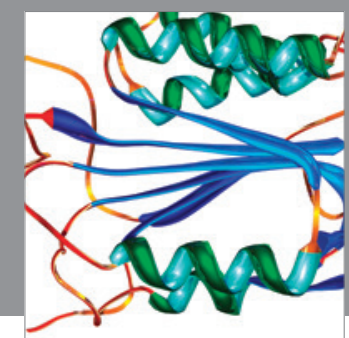

Disease Markers
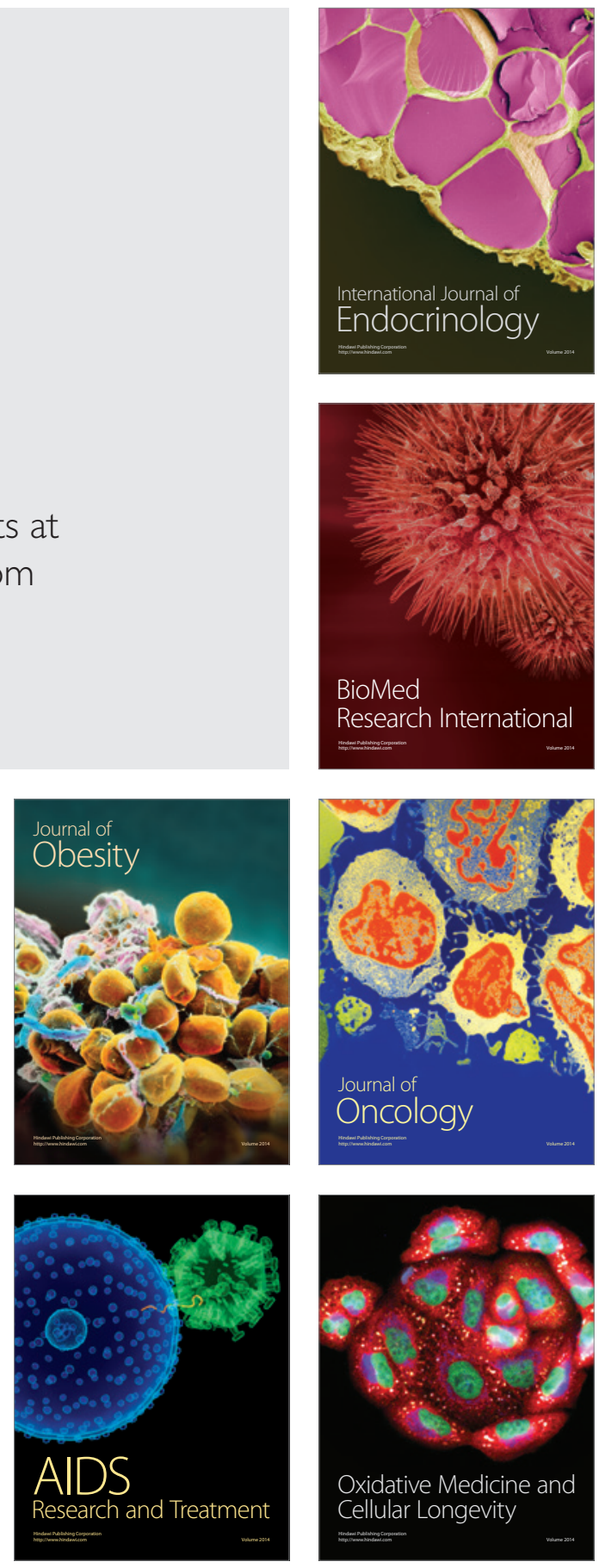